\title{
The role of acetic acid bacteria in brewing and their detection in operation
}

\author{
Petra Kubizniaková, Lucie Kyselová, Martina Brožová, Katarína Hanzalíková, Dagmar Matoulková \\ Research Institute of Brewing and Malting, \\ Lípová 511/15, 12000 Prague, Czech Republic \\ * corresponding author: kubizniakova@beerresearch.cz
}

\begin{abstract}
Acetic acid bacteria $(A A B)$ are often considered a threat of the past because today's equipment allows performing post-fermentation processes under a greatly reduced level of oxygen. This paper deals with the current importance of $A A B$ in brewing. The risk of contamination as well as the functional role in spontaneously fermented sour beers is reviewed. The main harmful effect of $A A B$ lies in the direct spoilage of draft beer and the formation of biofilms, most often in dispensing systems. On the contrary, $A A B$ seems to be indispensable in the case of sour beer production. $A$ key issue of $A A B$ in the brewing environment is their (early) detection and identification. Therefore, a part of this study is devoted to both, the latest sophisticated methods and primarily those of traditional cultivation which are still prevalent in operating laboratories due to their low cost and easy implementation. Finally, an experimental and pictorial material is added as a guide for operations that have less experience with AAB.
\end{abstract}

Keywords: aerobic bacteria, acetic acid bacteria, Acetobacter, Gluconobacter, biofilm, brewing

\section{Introduction}

A group of gram-negative bacteria capable of oxidizing ethanol or sugar to acetic acid is known as acetic acid bacteria (AAB). These bacteria were discovered more than 150 years ago by Louis Pasteur who first described these microorganisms as agents for vinegar production (Lynch et al., 2019; Hommel and Ahnert, 1999). AAB are widespread and abundant in the environment, especially where alcoholic fermentation takes place. Several species of $\mathrm{AAB}$ are used in food industry e.g. to produce vinegar, kombucha, kefir, acidic beer, cocoa-based products, coffee, etc. (Papalexandratou et al., 2009; Vuyst et al., 2008; González et al., 2005; Gupta et al., 2001). They are also employed in various pharmaceutical industry and biotechnological applications in which some of their metabolites such as D-gluconic acid, L-sorbose or dihrydroxyacetone can be used (Paradh, 2015; Wang et al., 2015; Vuyst et al., 2008; Gupta et al., 2001). Further, production of biopolymers such as cellulose or acetan should be mentioned as well as the significance of $\mathrm{AAB}$ in vitamin $\mathrm{C}$ production (Lynch et al., 2019; Papalexandratou et al., 2009).
On the other hand, AAB also present a risk of undesirable contamination in biotechnological processes, namely spoilage of beverages e.g., wine, cider or beer. AAB damage the drink quality due to the formation of acetic acid that causes unpleasant vinegary taste and flavour accompanied by turbidity and ropiness (Gomes et al., 2018; Bartowsky and Henschke, 2008).

Several tens' years ago, AAB presented a serious problem in brewing industry. However, an implementation of modern technologies and equipment that enable high performance sanitation and maintenance of low level of oxygen helped to radically solve the issue concerning $A A B$ (Paradh, 2015). Nowadays, AAB are considered as low risk contaminants in breweries and thus their role has substantially changed.

This overview deals with the current role of $A A B$ in breweries and beer-associated places including restaurants, pubs, bars, etc. The conditions under which AAB can still manifest themselves as unpleasant contaminants spoiling beer are described. The role of indicator bacteria 
pointing to technological errors or hygienic deficiency is underlined. And their relevance in the production of spontaneously fermented sour beers is also mentioned. The emphasis of this work is put on the methods of detection and identification of $\mathrm{AAB}$ directly in the production process or in dispensing system. The literature review is thus supplemented by several experimental data supported by pictorial material which breweries could facilitate to understand the AAB issue.

\section{General characteristic of acetic acid bacteria}

The AAB belong to the family of Acetobacteraceae as a branch of acidophilic bacteria in the $\alpha$-subdivision of the Proteobacteria which currently comprises 47 genera with validly published names according to the List of Prokaryotic names with Standing in Nomenclature (Parte et al., 2020) or NCBI taxonomy database (Schoch et al., 2020). So far, only two genera have been important for the brewing environment. Namely Acetobacter including 39 species and Gluconobacter with its 20 species validly published under the International Code of Nomenclature of Prokaryotes (ICNP) up to date. However, due to a constantly changing taxonomic classification of $\mathrm{AAB}$, the genera Gluconoacetobacter and Komagataeibacter are also likely to become known as significant in the brewery environment.

$\mathrm{AAB}$ are gram-negative, non-sporulating bacteria which usually have strictly aerobic metabolism with oxygen as a terminal electron acceptor. They are catalase-positive, oxidase negative cocci or rod-shaped cells of various lengths occurring individually or in chains. They belong to mesophilic microorganisms whose optimal growth temperature lies in the range of $25-30^{\circ} \mathrm{C}$. The maximum temperature at which they are able to grow is below $37^{\circ} \mathrm{C}$. The optimal pH for growth is between 5.0-6.5 (Paradh, 2015; Sievers and Swings, 2015; Wang et al., 2015; Sengun and Karabiyikli, 2011). In terms of nutrient requirements, $\mathrm{AAB}$ are classified as nutritionally undemanding microorganisms. They are able to use glucose, ethanol, arabinose, fructose, galactose, mannitol, mannose, ribose, sorbitol and xylose as carbon sources.

One of the most important metabolic characteristics is an ability to oxidize ethanol, sugars or sugar alcohol to corresponding organic acids, aldehydes or ketones under aerobic conditions. This oxidation can occur in neutral or acidic $\mathrm{pH}$ around the value 4.5 (Lynch et al., 2019; Wang et al., 2015; Papalexandratou et al., 2009). Produced organic acids are released and accumulated in external space which leads to acidification of the environment in order to prevent the growth of competitors. AAB are equipped with several mechanisms to cope with this acidity. These mechanisms are described in detail in e.g. Wang et al. (2015). Moreover, these accumulated acids can be, after depletion of other carbon sources, completely oxidized to carbon dioxide and water to sustain the growth (De Roos and De Vuyst, 2018; Sievers and Swings, 2015).

Genus Acetobacter - ellipsoidal to rod-shaped cells with a size of $0.6-1.0 \times 1.0-4.0 \mu \mathrm{m}$ occurring as single cells, in pairs and in chains. They are either non-motile or motile due to peritrichous flagella. Non-spore-forming, gram-negative, obligately aerobic, catalase positive, oxidase negative. They are classified among chemoorganotrophic organisms with the best utilization of ethanol, glycerol and glucose. Optimal conditions for their growth are temperature around $30{ }^{\circ} \mathrm{C}$ and $\mathrm{pH}$ in the range 4-6. They are ubiquitous and can be isolated for example from flowers and fruits. They are a common contaminant of fermented meat, wine, beer, sake or cider. A pathogenic effect on human bodies has not been described (Sievers and Swings, 2015; Hommel and Ahnert, 1999). In breweries, the genus Acetobacter was isolated from wort, beer line, KEGs, biofilms and beer that was aged in KEGs for a long period of time. Contaminated beers were cloudy, with increased viscosity and exhibited a sour acetic taste and odour due to production of acetic acid (González et al., 2005; Van Vuuren and Priest, 2003; McDonnell and Russell, 1999; Ingledew, 1979).

Genus Gluconobacter - ellipsoidal to rod-shaped cells with a size of $0.5-1.0 \times 2.6-4.2 \mu \mathrm{m}$ occurring as single cells and/or in pairs, occasionally in chains. They are either non-motile or motile due to 3-8 polar flagella. Nonspore-forming, gram-negative, obligately aerobic, catalase positive, oxidase negative. Most strains are able to utilize ethanol, mannitol, fructose, glucose, maltose, glycerol and xylose. The members of this genus are capable of ketogenesis that means the formation of ketone compounds from polyols. optimal conditions for their growth are temperature around $25-30{ }^{\circ} \mathrm{C}$ and $\mathrm{pH}$ in the range 5-6. However, most strains are able to grow even at $\mathrm{pH}$ 3.5. The strains were isolated for example from flowers, fruits, wine, cider or beer (Sievers and Swings, 2015). In breweries, the genus Gluconobacter was isolated from wort, beer line and KEGs. Contaminated beers were cloudy, with a sour acetic taste and odour due to production of acetic acid, which can dissociate into acetate (González et al., 2005; Van Vuuren and Priest, 2003; McDonnell and Russell, 1999; Ingledew, 1979). The basic differences between both genera are summarized in Table 1.

Due to metabolic characteristics, the genus Acetobacter thrives in the brewing environment better than members of the genus Gluconobacter. 
Table 1 Basic characteristics of AAB important in brewing (Gomes et al., 2018; Paradh, 2015)

\begin{tabular}{|l|c|c|}
\hline Selected characteristic & Acetobacter & non-motile \\
\hline motility & peritrichous & non-motile \\
\hline flagella arrangement & + & + \\
\hline ox. of ethanol to acetic acid & + & - \\
\hline ox. of acetic acid to $\mathrm{CO}_{2}$ and $\mathrm{H}_{2} \mathrm{O}$ & - & - \\
\hline ox. of lactic acid to $\mathrm{CO}_{2}$ and $\mathrm{H}_{2} \mathrm{O}$ & - & - \\
\hline formation of acid from raffinose & - & + acetic acid \\
\hline production of water-soluble brown pigment & acetic acid/acetate \\
\hline major metabolites produced in beer & acter \\
\hline
\end{tabular}

\section{The role of acetic acid bacteria in brewing}

The members of genera Acetobacter and Gluconobacter used to be feared contaminants in breweries due to conversion of ethanol to acetic acid or acetates resulting in vinegary off-flavours and formation of turbidity and slime (Sakamoto and Konings, 2003). AAB characteristics such as ability to survive in environments with high ethanol concentration $(>10 \% \mathrm{v} / \mathrm{v})$ and low $\mathrm{pH}(<\mathrm{pH} \mathrm{3.8)}$ ) and the resistance to bitter hop substances allowed them to thrive in the brewing environment. Nevertheless, nowadays beer production takes place with an emphasis on the elimination of oxygen in (post)-fermentation processes and thus the growth of AAB is suppressed by low concentration of oxygen. They are not currently considered as risky contaminants, especially in large breweries (Vriesekoop et al., 2012).

Despite the high modernization of beer production described above and strong antimicrobial properties of beer itself, AAB should be still considered as significant member of potentially occurring microbial communities in breweries. An overview of AAB recently isolated from brewing environment is listed in Table 2.

AAB can be divided into three groups according to their specific activity in a brewery:

- contaminants that spoil beer or a semi-finished product;

- contaminants as indicator microorganisms;

- production microorganisms - part of production consortium.

Beer spoilers. AAB can enter into breweries with raw materials (water, malt, wort extract, yeast) (Back, 2005) or via returning contaminated empty KEGs from consumers (Paradh, 2015; Back, 2005). Their spoiling activity results in the formation of slime and turbidity, decrease of alcohol content due to undesirable production of acetic acid. Such beer can be ropy because of bacterial polysaccharides and is characterized by an unpleasantly changed taste and flavour (Paradh, 2015; Storgårds, 2000).

Ploss et al. (1979), who studied 1203 samples taken from brewing production (from raw materials to finished beer), found 153 samples positive for $\mathrm{AAB}$. The authors concluded that $\mathrm{AAB}$ are more common in lager cellars, filtration processes and filling plants. The most frequent member (70 \%) belonged to A. pasteurianus subsp. pasteurianus (Ploss et al., 1979). A lower incidence of AAB was noted in samples from the main fermentation and storage tanks of input raw materials (Hill, 2015). Cases of beer contamination in KEG barrels were described as well (Ingledew, 1979). The cause of bacterial contamination in KEGs can occur when using air as a pressure medium without an integration of a suitable microbial filter behind compressor outlet.

It is necessary to mention that mini-breweries are more susceptible to AAB contamination as sanitation does not take place under such strict conditions, and modern bottling technologies are usually not installed.

Another critical area from the contamination point of view including $A A B$ incidents is a dispensing system in restaurants, pubs, bars, etc. While AAB are already pretty rare in beer production, they can be captured in draught beer in relatively high amounts. The problem of tap equipment together with beer lines is presence of oxygen and higher temperature in some parts of this system in combination with insufficient hygiene (Jevons and Quain, 2021). These cases have led to a repeatedly confirmed finding that some AAB strains are able to survive under limitation of oxygen (De Roos et al., 2018; Van Vuuren and Priest, 2003), in other words the traces of oxygen are enough to maintain viability. The most problematic points are poorly accessible and thus insufficiently sanitized places with air access such as taps, valves, space under seal, cavities, beer lines, tap stools. The growth of few attached bacteria occurs very fast either as single cells or with the formation of a highly resistant biofilm. It is very difficult to remove such a biofilm from an invaded place (Back, 2005). 
Table 2 The acetic acid bacteria (AAB) detected in breweries

\begin{tabular}{|c|c|c|c|}
\hline Current name of $\mathrm{AAB}$ & Alternative name & Source & References \\
\hline \multirow[b]{2}{*}{ unspecified $A A B$} & \multirow[b]{2}{*}{-} & fermentation of Belgian red-brown ale & Snauwaert et al. (2016) \\
\hline & & $\begin{array}{l}\text { collection vessel fermentation and } \\
\text { storage tanks }\end{array}$ & van Vuuren et al. (1979) \\
\hline \multicolumn{4}{|c|}{ genus Acetobacter } \\
\hline A. aceti & - & fermentation of lambic beer & De Roos and De Vuyst (2018) \\
\hline A. cerevisiae & - & spoiled beer & $\begin{array}{l}\text { Wieme et al. (2014) } \\
\text { Cleenwerck et al. (2002) }\end{array}$ \\
\hline \multirow{3}{*}{ A. fabarum } & \multirow{3}{*}{-} & drought beer & Jevons et al. (2021) \\
\hline & & spoiled beer & Wieme et al. (2014) \\
\hline & & fermentation of American coolship ale & Bokulich et al. (2012) \\
\hline \multirow{2}{*}{ A. indonesiensis } & \multirow{2}{*}{-} & fermentation of lambic beer & De Roos and De Vuyst (2018) \\
\hline & & spoiled beer & Wieme et al. (2014) \\
\hline A. lambici & - & fermentation of lambic beer & $\begin{array}{l}\text { De Roos and De Vuyst (2018) } \\
\text { Spitaels, Li et al. (2014) }\end{array}$ \\
\hline \multirow{2}{*}{ A. lovaniensis } & \multirow{2}{*}{$\begin{array}{l}\text { A. pasteurianus subsp. } \\
\text { lovaniensis }\end{array}$} & fermentation of lambic beer & De Roos and De Vuyst (2018) \\
\hline & & fermentation of American coolship ale & Bokulich et al. (2012) \\
\hline A. orientalis & - & fermentation of lambic beer & De Roos and De Vuyst (2018) \\
\hline A. orleanensis & $\begin{array}{l}\text { A. aceti subsp. } \\
\text { orleanensis }\end{array}$ & spoiled beer & $\begin{array}{c}\text { Wieme et al. (2014) } \\
\text { Cleenwerck et al. (2002) }\end{array}$ \\
\hline \multirow{4}{*}{ A. pasteurianus } & \multirow{4}{*}{ A. ascendens } & (spoiled) beer, microbrewery surface & $\begin{array}{l}\text { De Roos and De Vuyst (2018) } \\
\text { Gonzáles et al. (2004) }\end{array}$ \\
\hline & & microbrewery surface & Maifreni et al. (2015) \\
\hline & & fermentation of Belgian red-brown ale & Snauwaert et al. (2016) \\
\hline & & fermentation of lambic beer & De Roos et al. (2020) \\
\hline $\begin{array}{l}\text { A. pasteurianus subsp. } \\
\text { pasteurianus }\end{array}$ & - & cellar, filtration, filling & $\begin{array}{l}\text { Vriesekoop et al. (2012) } \\
\text { Ploss et al. (1979) }\end{array}$ \\
\hline A. persici & - & spoiled beer & Wieme et al. (2014) \\
\hline A. pomorum & - & fermentation of lambic beer & De Roos et al. (2020) \\
\hline \multirow{3}{*}{$\begin{array}{l}\text { not specified } \\
\text { Acetobacter }\end{array}$} & \multirow{3}{*}{-} & $\begin{array}{c}\text { wort, beer dispenses, cask-conditioned } \\
\text { beer, barrel-aged beer, biofilms in } \\
\text { brewery }\end{array}$ & $\begin{array}{c}\text { Paradh (2015) } \\
\text { Vriesekoop et al. (2012) }\end{array}$ \\
\hline & & spoiled beer & Wieme et al. (2014) \\
\hline & & fermentation of lambic beer & De Roos et al. (2020) \\
\hline \multicolumn{4}{|c|}{ genus Gluconobacter } \\
\hline \multirow{3}{*}{ G. cerevisiae } & \multirow{3}{*}{-} & fermentation of lambic beer & $\begin{array}{l}\text { Spitaels, Wieme et al. (2014) } \\
\text { De Roos and De Vuyst (2018) }\end{array}$ \\
\hline & & spoiled brewer's yeast & Spitaels, Wieme et al. (2014) \\
\hline & & spoiled beer & Wieme et al. (2014) \\
\hline G. cerinus & - & spoiled beer & Wieme et al. (2014) \\
\hline G. japonicus & - & spoiled beer & Wieme et al. (2014) \\
\hline \multirow[t]{2}{*}{ G. oxydans } & \multirow[t]{2}{*}{-} & brewing environment, beer & $\begin{array}{c}\text { Paradh (2015) } \\
\text { Gonzáles et al. (2004) }\end{array}$ \\
\hline & & spoiled beer & Wieme et al. (2014) \\
\hline G. wancherniae & - & fermentation of lambic beer & De Roos and De Vuyst (2018) \\
\hline \multirow{2}{*}{$\begin{array}{l}\text { not specified } \\
\text { Gluconobacter }\end{array}$} & \multirow[t]{2}{*}{-} & $\begin{array}{c}\text { wort, beer dispenses, cask-conditioned } \\
\text { beer }\end{array}$ & $\begin{array}{c}\text { Paradh (2015) } \\
\text { Vriesekoop et al. (2012) }\end{array}$ \\
\hline & & spoiled beer & Wieme et al. (2014) \\
\hline
\end{tabular}


Indicator bacteria. We can talk about indicator microorganisms (MOs) when they do not cause spoilage but they appear as a consequence of insufficient cleaning or errors in production. Thus their presence is often associated with the occurrence of current frightening beer spoilers and indicates deteriorated hygienic level or technological errors (Paradh, 2015; Back, 2005; Storgårds, 2000). The real harmfulness of detected AAB lies mainly in the formation of biofilms as they are one of the first microorganisms attaching to various types of surfaces. Critical points in terms of a microbial biofilm formation in brewing operations are those places (e.g. corners, folds, niches, etc.) that are hard to access while sanitary cleaning (mechanical and/or chemical). Residues of process intermediates, finished beer or other liquids are remains in such places and thus present a favourable environment for gradual development of a microbial biofilm. The first step of the biofilm formation is a colonization of a suitable surface under aerobic conditions by $\mathrm{AAB}$ together with some enterobacteria. These bacteria are not considered harmful in beer and may not even be detected. Nevertheless, their long-term biological activity causes slime coating of the surface (Storgårds, 2000) because many of AAB members are able to produce high levels of polysaccharides, among which the main are cellulose, dextran and levan (Paradh, 2015; Gullo and Giudici, 2008). In this manner, AAB create a suitable and protected environment for other MOs such as yeasts. Thus, yeasts start to grow together with $\mathrm{AAB}$ in the environment of polysaccharides and other nutrients, and produce other essential factors promoting the growth of lactic acid bacteria (LAB). LAB on the other hand accumulate lactic acid which can serve as a carbon and energy source for anaerobic bacteria, e.g. Pectinatus sp. or Megasphaera sp. (Maifreni et al., 2015; Timke et al., 2004; Storgårds, 2000).

The ability to form a biofilm on the number of surface materials has so far been proved in Acetobacter sp. (e.g. A aceti or A. pastorianus), and Gluconobacter oxydans (Storgårds, 2000).

As mentioned above, the biofilm initiated by AAB frequently appears at dispensing lines.

Functional role. AAB communities can be detected during fermentation and maturation of spontaneously fermented sour beers such as Belgic lambic beer or American coolship ale, etc. The production of these acidic ales lies in a long term (up to 3 years) microbial process which proceeds in wooden barrels. The basic sensorial characteristic of spontaneously fermented beers is their pleasant/refreshing acidity (De Roos et al., 2020; De Roos et al., 2018; Snauwaert et al., 2016; Spitaels, Wieme, et al., 2014; Bokulich et al., 2012). A part of this acidity is caused by $\mathrm{AAB}$. The role of $\mathrm{AAB}$ was until recently considered limited because they were only rarely isolated from sour beers production most likely due to the following reasons:

- They are not detectable in wort, their noticeable development starts after the first week of the fermentation process;

- Their amount and species diversity change over time (De Roos et al., 2018);

- Strictly aerobic AAB are more concentrated on the surface of wort where the oxygen is abundant. Hence, they are omitted due to typical submerged sampling of wort/beer (De Roos et al., 2018; De Roos and De Vuyst, 2018);

- Occurrence of AAB in a viable but not culturable state (De Roos and De Vuyst, 2018);

- Their count and species diversity are specific for each brewery and the character of surroundings, moreover spontaneous fermentation is natural, variable and hardly predictable (Snauwaert et al., 2016).

Exploration of the spontaneous microbial consortia during acidic beer fermentation led to an isolation and detection of two new species of AAB, namely Acetobacter lambici (Spitaels, Li, et al., 2014) and Gluconobacter cerevisiae (Spitaels, Wieme, et al., 2014).

Also De Roos et al. (2018) dealt with the role and occurrence of $\mathrm{AAB}$ in lambic beer production and identified $359 \mathrm{AAB}$ isolates in beer samples taken from two wooden casks where a 24-month fermentation/maturation took place. They found that species of genus Acetobacter, including A. orientalis, A. pasteurianus, or A. lambici, predominated over Gluconobacter species such as G. cerevisiae. The monitored metabolic products were acetic acid, little of gluconic acid, ethyl acetate and acetoin. This study looked at the AAB counts as a function of fermentation/ maturation time.

The authors also confirmed that AAB can survive under limitation of oxygen.

Recently, this research team has published temporal metagenomic analysis which found $\mathrm{AAB}$, represented by genera Acetobacter and Komagataeibacter, as the most abundant bacteria at the beginning and during the first 3 months of fermentation. Lower amount of AAB has proved to persist in the fermenting beer until the late stages of maturation (De Roos et al., 2020).

Although AAB play an essential role in acidic beer production, their excessive development is not desirable as too high concentration of acetic acid and acetoin can lead to a disharmonious sensory profile of the final product. Due to natural regulation of AAB caused by a limited access of oxygen, it is sufficient not to miss the routine control of $\mathrm{AAB}$ during processing. 


\section{Detection and Identification Methods of Acetic Acid bacteria}

There are many traditional and modern techniques of $\mathrm{AAB}$ detection and identification that are crucial mainly in food processing, either to solve contamination incidents or to monitor microbial community during spontaneous fermentation. Traditional methods are based on physiological and chemotaxonomical properties, e.g. growth at low $\mathrm{pH}$, production of acetic and/or gluconic acid from ethanol and/or glucose, or growth in the presence of $0.35 \%$ (v/v) acetic acid etc. (Vuyst et al., 2008). These cultivation techniques are inexpensive and require only common laboratory equipment. However, they are quite time-consuming and their reliability is not $100 \%$ (González et al., 2004; Storgårds, 2000). Established culture media often underestimate microbial populations in many systems, and furthermore a large proportion of the microbial cells can be in a non-culturable state caused by environmental stress such as oxygen deprivation (González, Hierro, et al., 2006; Storgårds, 2000). However, the cultivation method is still widely used for the enumeration of microbes (Storgårds, 2000) as well as a routine detection technique. In order to overcome these disadvantages, the cultivation methods have been complemented or replaced by modern molecular or instrumental techniques, see several examples stated in Table 3.

Genera Acetobacter and Gluconobacter are not nutritionally demanding. However, the most suitable carbon sources for Acetobacter are ethanol, glycerol and D-lactate, while for Gluconobacter it is D-mannitol, sorbitol, glycerol, D-fructose and D-glucose (Gullo et al., 2006). The choice of an appropriate medium depends on a particular goal e.g. strain isolation from spontaneous fermentation, study of a biofilm in operation or control of potential contamination. A number of diagnostic culture media are mentioned in scientific literature. The basis of these diagnostic media can be ethanol or acetic acid together with ethanol as well as diverse media containing various combinations of glucose, sorbitol together with mannitol or glucose medium with $\mathrm{CaCO}_{3}$ and ethanol, etc. The nutritional supplement is usually peptone and/ or yeast extract (Gomes et al., 2018; Sievers and Swings, 2015; Sengun and Karabiyikli, 2011). A number of media including their composition are mentioned for instance in Lynch et al. (2019), Wieme et al. (2014) or Hommel and Ahnert (1999).

The AAB strains can be isolated from complex matrices containing other microorganisms by reducing $\mathrm{pH}$ of the culture medium to the value 4.4 and/or by adding antimicrobial agents e.g. cycloheximide to inhibit yeasts or penicillin to inhibit lactic acid bacteria (Gullo et al.,
2006). Media relevant for the isolation of $A A B$ strains are described for example in Lynch et al. (2019).

The main aim of this article is to offer a guide for an ordinary brewing laboratory in order to help them with a basic AAB diagnosis. The so-called chalk-ethanol test can be used for this purpose. This medium is among others used for phenotypic differentiation of $A A B$ - cultivated $\mathrm{AAB}$ dissolves added $\mathrm{CaCO}_{3}$ which results in the formation of transparent zones in the medium. Subsequent oxidation of acetic acid, which only some members are capable of, leads to a gradual re-formation of solid $\mathrm{CaCO}_{3}$, which results in the formation of milky turbidity in the medium (Sievers and Swings, 2015). Calcium carbonate is a part of Frateur's medium and GYC agar.

The production of acetic acid during the bacterial growth and its subsequent oxidation considerably changes the $\mathrm{pH}$ of the culture medium. This ability is used to rapid phenotypic differentiation of AAB on Carr's medium with the addition of bromcresol blue.

The detection of AAB is not performed routinely in operational brewing laboratories because their harmfulness is not so serious and lies mainly in their ability to form a biofilm. Their identification is therefore carried out especially in situations where the overall microbiological quality of beer is deteriorated due to a technological error or insufficient sanitation. The most critical point is filling equipment such as impact heads or taps.

\section{Experimental supplement materials}

The recommended detection of AAB useful for brewing laboratories is described above, however, the authors believe that specific examples accompanied by pictorial documentation from our laboratory could be useful.

\subsection{Culture Media}

- Meat Peptone Agar (MPA), preparation: Dissolving $20 \mathrm{~g}$ of dehydrated nutrient agar (Merck) in 1,000 ml of distilled water. The prepared soil is light yellow.

- Carr Medium, preparation: Dissolving $30 \mathrm{~g}$ of a yeast extract (Merck) + $20 \mathrm{ml}$ ethanol (Lach:mer) + 20 g bacteriological agar (Oxoid) +0.022 g bromcresol green (Lachema) in 1,000 $\mathrm{ml}$ of distilled water. The prepared soil is green-blue.

- Frateur Medium, preparation: Dissolving $30 \mathrm{~g}$ of a yeast extract (Merck) $+20 \mathrm{ml}$ of ethanol (Lach:mer) +20 g bacteriological agar (Oxoid) +20 g calcium carbonate (Sigma) in 1,000 $\mathrm{ml}$ of distilled water. The prepared soil is light yellow and turbidity appears due to insoluble $\mathrm{CaCO}_{3}$.

- GYC Agar, preparation: Dissolving $10 \mathrm{~g}$ of a yeast extract (Merck) + 100 g glucose (Merck) + 15 g bacteri- 
Table 3 An overview of modern detection and identification methods suitable for $A A B$

\begin{tabular}{|c|c|c|c|}
\hline Method & Level of differenciation & Source & References \\
\hline \multicolumn{4}{|c|}{ DNA/RNA-dependent molecular techniques } \\
\hline \multirow{6}{*}{ DNA:DNA hybridizations } & \multirow{6}{*}{ species } & fermentation of lambic beer & Spitaels, Li et al. (2014) \\
\hline & & brewery environment & Spitaels et al. (2014) \\
\hline & & fruits, flowers and related material & Tanasupawat et al. (2009) \\
\hline & & fermented cocoa beans & Vuyst et al. (2008) \\
\hline & & apple juice & Dellaglio et al. (2005) \\
\hline & & collection strains & $\begin{array}{l}\text { Cleenwerck et al. (2002) } \\
\text { Lisdiyanti et al. (2000) }\end{array}$ \\
\hline \multirow{3}{*}{ PCR-RFLP $16 \mathrm{~S}$ rRNA } & \multirow{3}{*}{ species } & $\begin{array}{l}\text { grapes, fresh grape must, } \\
\text { wine fermentation }\end{array}$ & Gonzáles et al. (2005) \\
\hline & & wine fermentation & $\begin{array}{l}\text { Gonzáles, Guillamón et al. (2006) } \\
\text { Ruiz et al. (2000) }\end{array}$ \\
\hline & & collection strains & $\begin{array}{c}\text { Gonzáles, Hierro et al. (2006) } \\
\text { Gonzáles, Guillamón et al. (2006) } \\
\text { Poblet et al. (2000) }\end{array}$ \\
\hline \multirow{2}{*}{ PCR-RFLP 16S rDNA } & \multirow{2}{*}{ species } & fresh grape must, & \multirow{2}{*}{ Gonzáles et al. (2004) } \\
\hline & & red wine fermentation & \\
\hline & & fruits, flowers and related material & Tanasupawat et al. (2009) \\
\hline $\begin{array}{l}\text { PCR-RFLP 16S-23S rRNA/ } \\
\text { rDNA }\end{array}$ & species & collection strains & $\begin{array}{c}\text { Tanasupawat et al. (2009) } \\
\text { Gonzáles, Guillamón et al. (2006) } \\
\text { Trcek (2005) } \\
\text { Trcek and Teuber (2002) } \\
\text { Ruiz et al. (2000) }\end{array}$ \\
\hline PCR-RFLP 16S-23S-5S rDNA & species & traditional balsamic vinegar & Gullo et al. (2006) \\
\hline PCR-TRFLP & species & fermentation of American coolship ale & Bokulich (2012) \\
\hline \multirow{4}{*}{ RAPD fingerprinting } & \multirow{4}{*}{ strain } & brewery environment & Spitaels et al. (2014) \\
\hline & & bottled wine & Bartovsky et al. (2003) \\
\hline & & spirit vinegar & Trcek et al. (1997) \\
\hline & & rice vinegar & Nanda et al. (2001) \\
\hline MLST/MLSA & not specified & brewery environment & Spitaels et al. (2014) \\
\hline \multirow{2}{*}{ PCR-DGGE } & \multirow{2}{*}{ species } & wine fermentation & Andorra et al. (2008) \\
\hline & & traditional balsamic vinegar & De Vero et al. (2006) \\
\hline \multirow[t]{2}{*}{ ERIC-PCR } & \multirow[t]{2}{*}{ strain } & $\begin{array}{c}\text { grape surface } \\
\text { grape must } \\
\text { wine fermentation }\end{array}$ & Gonzáles et al. (2005) \\
\hline & & rice vinegar & Nanda et al. (2001) \\
\hline REP-PCR & strain & $\begin{array}{l}\text { grape surface } \\
\text { grape must } \\
\text { wine fermentation }\end{array}$ & Gonzáles et al. (2005) \\
\hline \multirow{2}{*}{ (GTG)5-rep-PCR fingerprinting } & \multirow{2}{*}{ strain } & collection strains & Papalexandratou et al. (2009) \\
\hline & & fermented cocoa beans & Vuyst et al. (2008) \\
\hline 454 Pyrosequencing & species & fermentation of Belgian red-brown ale & Snauwaert et al. (2016) \\
\hline methagenomic DNA analysis & genus/species & lambic beer fermentation & De Roos et al. (2020) \\
\hline \multicolumn{4}{|c|}{ Other non-DNA/RNA-dependent techniques } \\
\hline \multirow{4}{*}{ MALDI-TOF-MS } & \multirow{4}{*}{ species } & lambic beer fermentation & De Roos et al. (2018) \\
\hline & & fermentation of lambic beer & Spitaels, Li et al. (2014) \\
\hline & & brewery environment & Spitaels et al. (2014) \\
\hline & & $\begin{array}{l}\text { collection strain originating from } \\
\text { brewery environment, spoiled beers }\end{array}$ & Wieme et al. (2014) \\
\hline
\end{tabular}

PCR - Polymerase Chain Reaction; RFLP - Restriction Fragment Length Polymorphism; RAPD - Ramdomply Amplified Polymorphic DNA; MLST - Multilocus Sequence Typing/Analysis; DGGE - denaturating gradient gel electrophoresis; ERIC - Enterobacterial Repetitive Intergenic Consensus; REP - Repetitive Extragenic Palindromic; MALDI - Matrix-Assisted Laser Desorption/Ionization; TOF - Time-of-Flight; MS - Mass Spectrometry 
ological agar (Oxoid) +20 g calcium carbonate (Sigma) in 1,000 ml of distilled water. The prepared soil is light yellow and turbidity appears due to insoluble $\mathrm{CaCO}_{3}$.

- WLN medium, preparation: Dissolving $75 \mathrm{~g}$ of dehygrated WL nutrient agar (Merck) in 1,000 ml of distilled water.

The all-above-mentioned media were sterilized for $20 \mathrm{~min}$ at $121^{\circ} \mathrm{C}$.

\subsection{Selected acetic acid bacteria and their culture conditions}

The bacterial strains used in this work come from the Czech Collection of Microorganisms (CCM) in Brno, Czech Republic.

The list of selected strains, their designation and origin are given in Table 4.

The strains were incubated under aerobic conditions on an MPA medium at $28{ }^{\circ} \mathrm{C}$ for $48 \mathrm{~h}$ before inoculation on a specific testing media. The cultures were then inoculated by cross-spreading on the testing media. Incubation was performed repeatedly under aerobic conditions at the optimal growth temperature (Table 4). The time of cultivation was 3 to 5 days and the bacterial growth was monitored on a daily basis.

\subsection{Pictorial material}

Diagnostic media. On the basic of culture medium MPA, all selected strains of $\mathrm{AAB}$ grew in the form of flat round smooth glossy colonies of white to slightly cream colour as stated by Back (2005). The fundamental diagnostic characteristic of $\mathrm{AAB}$ is an ability to oxidize ethanol to acetic acid, which is released into the medium, as mention above. The genera Acetobacter and Gluconacetobacter can further oxidize the acetic acid to $\mathrm{CO}_{2}$ and water after depletion of ethanol (Sievers and Swings, 2015) while Gluconobacter lacks this ability and acetic acid is thus the final product of its metabolism (Kersters et al., 2006). Phenotypic differentiation of the genera Acetobacter and
Gluconobacter on Carr's medium is based on this metabolic variance. The Carr's medium contains bromcresol green as a $\mathrm{pH}$ indicator. The formation of acetic acid is then indicated by a colour change from the originally bluegreen to yellow where the subsequent re-bluing indicates re-increased $\mathrm{pH}$ due to the production of $\mathrm{CO}_{2}$ and water (Sievers and Swings, 2015).

This apparent discoloration of Carr's agar appeared also during the cultivation of all selected AAB strains. The colour change was observable at the bacterial growth site as a result of acetic acid production after 48 hours of incubation (Figure $1 \mathrm{~A}$ and $2 \mathrm{~A}$ ). The medium re-darkened to the original blue-green coloration after prolonged incubation of strains belonging to genera Acetobacter (Figure 1B) and Gluconacetobacter. As previously mentioned, the representatives of the genus Gluconobacter do not have the ability of acetic acid oxidation, therefore this acid remains in the medium, hence the change of $\mathrm{pH}$ and re-coloration of agar to blue-green did not appear (Figure 2B).

It was also mentioned that calcium carbonate $\left(\mathrm{CaCO}_{3}\right)$ can be used to detect acetic acid production during cultivation of $\mathrm{AAB} . \mathrm{CaCO}_{3}$ is decomposed due to the effect of acetic acid which leads to the formation of $\mathrm{CO}_{2}$, water and soluble calcium acetate. This detection method was tested on GYC and Frateur's agars containing $\mathrm{CaCO}_{3}$. Glucose is

Table 4 The list of used strains of $A A B$, their collection, designation and origin.

\begin{tabular}{|l|c|c|c|}
\hline Bacterial Name according to CCM & Strain Designation & Origin & Optimal Growth Temperature \\
\hline Acetobacter aceti & CCM 3620 & wine & 30 \\
\hline Acetobacter pasteurianus & CCM $2374^{\top}$ & beer & 25 \\
\hline Gluconacetobacter hansenii & CCM 1808 & unknown & 25 \\
\hline Gluconacetobacter liquefaciens & CCM $3621^{\top}$ & dried fruit & 30 \\
\hline Gluconobacter oxydans & CCM $3607^{\top}$ & beer & 25 \\
\hline
\end{tabular}

CCM - Czech Collection of Microorganisms, Brno, Czech Republic 
a source of carbon and energy in GYC agar, while in Frateur's agar it is ethanol. Before inoculation, both media were light yellow accompanied by milky turbidity caused by undissolved $\mathrm{CaCO}_{3}$. Acetic acid produced during incubation dissolves $\mathrm{CaCO}_{3}$ and thus clarifies the culture medium. A so-called halo effect appears around the colonies (Lisdiyanti et al., 2000).

Only slow growth of the examined AAB was noticed on Frateur's agar during 120 hours of incubation, and no clear zones formed around the colonies, an exception were the areas with a dense culture. Cream-colored colonies were hard to detect (Figure 3A).

The composition of Frateur's agar is relatively unfavourable for rapid growth of $\mathrm{AAB}$ due to the absence of sugars. Hence, it is evaluated as less suitable for using in an operating laboratory. On GYC agar, growth of AAB was accompanied by the formation of more pronounced clarified zones, but again only in the areas with a dense culture (Figure $3 \mathrm{~B}$ ).

AAB can be caught also on WLN agar during routine microbiological analyses in a brewery. An example is the determination of the total number of aerobic germs or total number of aerobic bacteria when actidion is added. The growth of AAB is then manifested by a colour change of originally blue-green medium to bright yellow around the colonies (Figure 4).

AAB can grow on a Chromocult Coliform medium that is intended for the determination of coliform bacteria. $\mathrm{AAB}$ forms colourless to creamy colonies so they cannot be confused with coliform bacteria, whose colonies are pink-purple in this medium. However, the capture of $\mathrm{AAB}$ in this medium can occur only at cultivation temperatures up to $34^{\circ} \mathrm{C}$ as $\mathrm{AAB}$ are mesophilic microorganisms with an optimal growth temperature of about $30^{\circ} \mathrm{C}$. They do not grow when the temperature is above $34{ }^{\circ} \mathrm{C}$ (Lynch et al., 2019; Saichana et al., 2015).

Biofilms in breweries. Fig. 5-8 document unacceptably poor hygiene of brewery operation. The growth of a biofilm is extensive in the shown places and the risk of contact with beer or its intermediate product is high. These
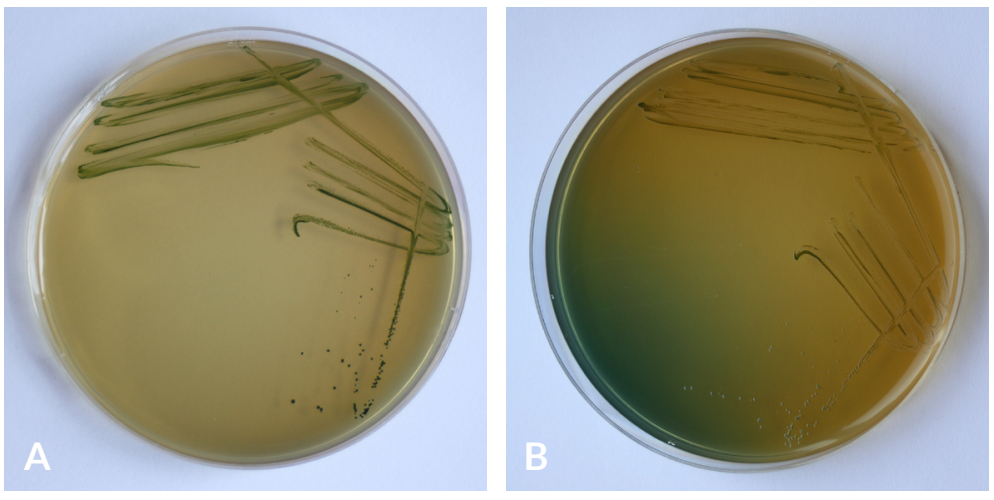

Figure 2 A - Discoloration of Carr's agar at the growth site of Gluconobacter oxydans CCM $3607^{\top}$ after 48 hours incubation due to acetic acid formation; $B$ - No re-coloration after prolonged incubation - acetic acid remains the final product of bacterial metabolism.
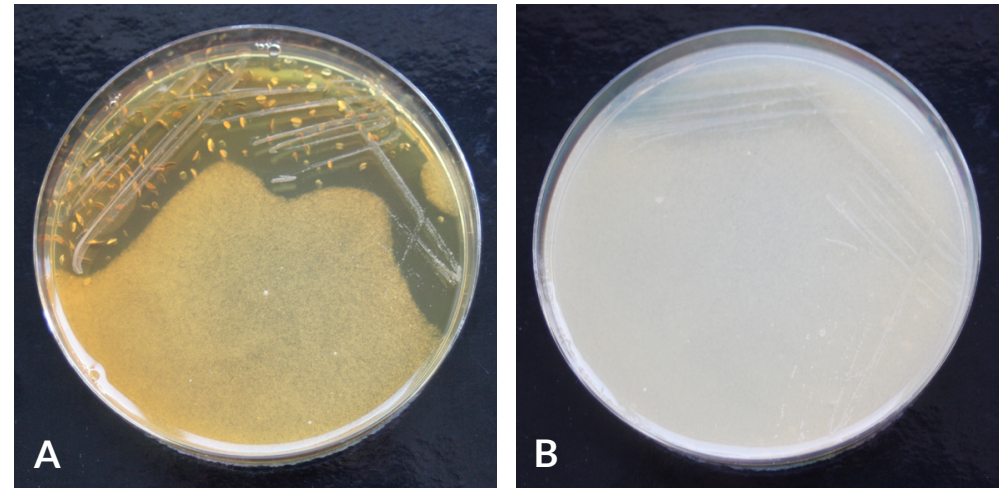

Figure 3 Cell growth of Gluconobacter oxydans CCM $3607^{\top}$ on Frateur's agar (A) and GYC agar (B) after 120 hours of incubation. The so-called halo effect, i.e. the zone where $\mathrm{CaCO}_{3}$ was dissolved by produced acetic acid, is visible only at the site of thicker culture coating.
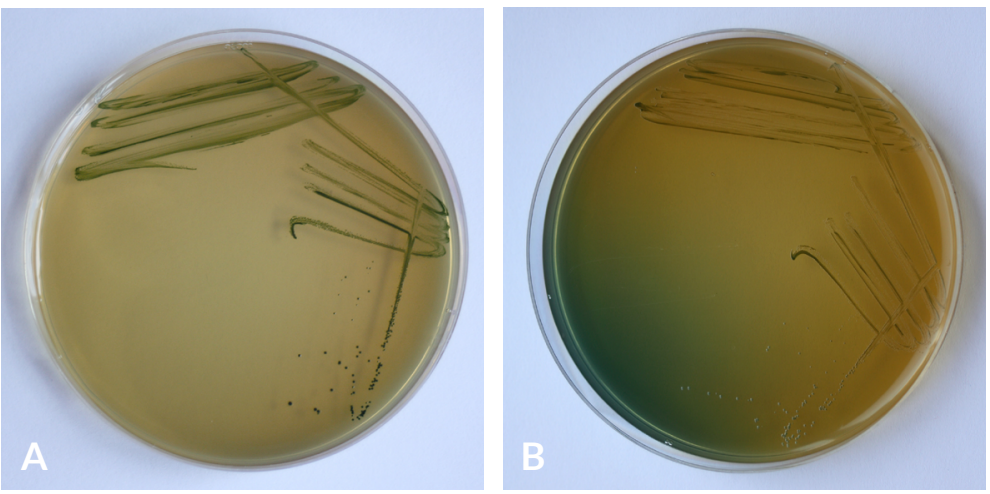

Figure 4 Cell growth of Gluconacetobacter hansenii CCM 1808 (A) and Acetobacter pasteurianus CCM $2374^{\top}$ (B) on WLN agar after 72 hours of incubation.

appalling conditions indicate that these places have not been sanitized for a long time and that regular sanitation is ineffective as usually only microorganisms on the surface of the biofilm are killed. The only effective method for a biofilm disposal is perfect mechanical cleaning just before sanitation itself.

Biofilm inside the sterilization tank at a yeast propagation plant (Fig. 5) is already starting to dry and microbes 


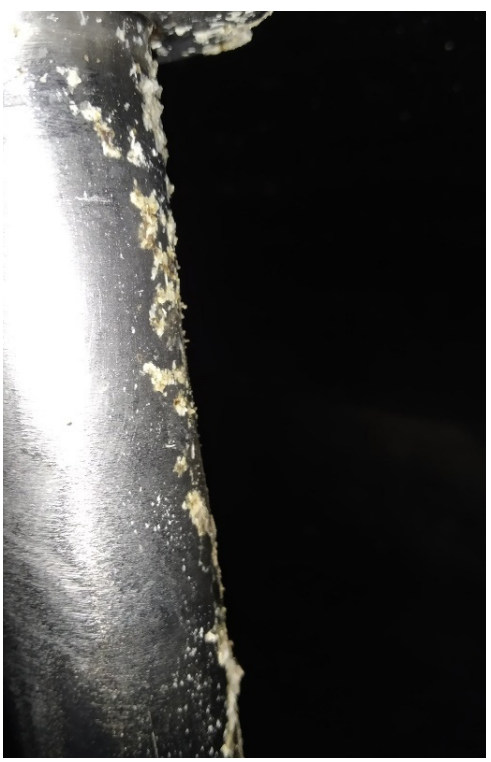
tank at a yeast propagation plant
Figure 5 Biofilm inside a sterilization

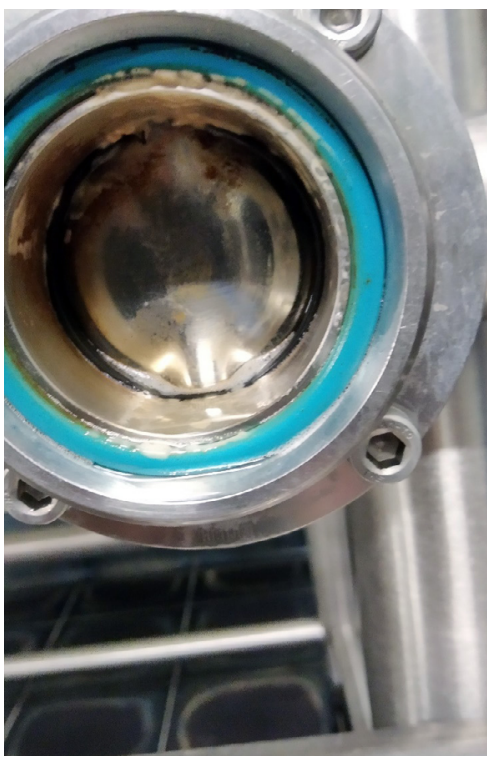

Figure 6 Flange on the pipe overgrown with active biofilm of contamination that causes microbial spoilage of beer.

\section{Conclusion}

A diverse role of AAB supplemented by modern and traditional methods for their detection and identification is discussed in this paper. Although AAB pose only a small risk of contamination compared to wild yeasts, lactic acid bacteria or strict anaerobes, their presence in brewing environment cannot be overlooked. Contamination by these bacteria is not so rare in draft beer and long-aged beers in KEGs. Their harmfulness lies mainly in an ability to form a biofilm which provides suitable conditions for the growth of truly harmful microorganisms. These bacteria should also be considered in the case of mini-breweries which usually do do not have a sufficient source of energy and water. Complete removal of this biofilm will be very difficult because it is a hard-to-reach interior place. Chemical washing and subsequent disinfection will certainly not be enough. Figure 6 shows a flange on the pipe overgrown with an active biofilm. Contamination of sealing elements, interior and damper itself is clearly distinguishable. The biofilm already penetrates through its seal into the pipe where it comes into contact with beer or its intermediate products. Although the biofilm is outside the production facility, it easily becomes a part of an internal/closed system. If a hose or elbow is fitted to such a contaminated flange without proper mechanical cleaning of the biofilm complemented by subsequent sanitation, impurities and primarily beer spoiling microorganisms living in biofilm layers will enter the product. Such a place is definitely a source not have any modern bottling technologies installed and do not have such high demands on sanitation. Moreover, the occurrence is associated with tap equipment and beer lines in restaurants and pubs where they indicate an insufficient level of hygiene together with an inappropriately selected pressure medium. Due to a low risk of AAB contamination, they are not routinely monitored in beer and brewing operations. If their presence is suspected, Carr's medium can be used for detection and at the same time for rapid phenotypic differentiation of AAB.

\section{Acknowledgement}

The work was supported by the Ministry of Agriculture of the Czech Republic (institutional support MZE-R01918).

Table 5 An overview of bacterial growth on tested culture media after 72 and 120 hours of incubation

\begin{tabular}{|c|c|c|c|c|c|c|c|}
\hline \multirow{3}{*}{$\begin{array}{l}\text { Bacterial name } \\
\text { according to CCM }\end{array}$} & \multirow{3}{*}{$\begin{array}{c}\text { Strain } \\
\text { designation }\end{array}$} & \multicolumn{6}{|c|}{ Culture medium } \\
\hline & & \multicolumn{2}{|c|}{ Carr's medium } & \multicolumn{2}{|c|}{ Frateur's medium } & \multicolumn{2}{|c|}{ GYC-agar } \\
\hline & & $72 \mathrm{hrs}$ & $120 \mathrm{hrs}$ & $72 \mathrm{hrs}$ & 120 hrs & 72 hrs & $120 \mathrm{hrs}$ \\
\hline Acetobacter aceti & CCM $3620^{\top}$ & + & + & $\sim$ & $\sim$ & + & + \\
\hline Acetobacter pasteurianus & CCM $2374^{\top}$ & + & + & + & + & + & + \\
\hline Gluconacetobacter hansenii & CCM 1808 & + & + & $\sim$ & $\sim$ & + & + \\
\hline Gluconacetobacter liquefaciens & CCM $3621^{\top}$ & + & + & $\sim$ & $\sim$ & + & + \\
\hline \multirow{2}{*}{ Gluconobacter oxydans } & CCM $3607^{\top}$ & $+^{*}$ & $+*$ & + & + & + & + \\
\hline & CCM 3617 & $+^{*}$ & $+^{*}$ & $\sim$ & + & + & + \\
\hline
\end{tabular}

+ growth; - no growth; slight growth

* no re-coloration 


\section{References}

Andorrà, I., Landi, S., Mas, A., Guillamón, J. M., Esteve-Zarzoso, B. (2008). Effect of oenological practices on microbial populations using culture-independent techniques. Food Microbiology, 25(7), 849-856. https://doi.org/10.1016/j.fm.2008.05.005

Back, W. (2005). Brewery. In W. Back (Ed.), Colour Atlas and Handbook of Beverage Biology (pp. 10-112). Nürnberg: Fachverlag Hans Carl.

Bartowsky, E. J., Xia, D., Gibson, R. L., Fleet, G. H., Henschke, P. A. (2003) Spoilage of bottled red wine by acetic acid bacteria. Letters in Applied Microbiology, 36(5), 307-314. https://doi.org/10.1046/j.1472765X.2003.01314.x

Bartowsky, Eveline J., Henschke, P. A. (2008). Acetic acid bacteria spoilage of bottled red wine - a review. International Journal of Food Microbiology, 125(1), 60-70. https://doi.org/10.1016/j.ijfoodmicro.2007.10.016

Bokulich, N. A., Bamforth, C. W., Mills, D. A. (2012). Brewhouse-resident microbiota are responsible for multi-stage fermentation of American coolship ale. PloS One, 7(4), e35507. https://doi.org/10.1371/ journal.pone.0035507

Cleenwerck, I., Vandemeulebroecke, K., Janssens, D., Swings, J. (2002) Re-examination of the genus Acetobacter, with descriptions of Acetobacter cerevisiae sp. nov. and Acetobacter malorum sp. nov. International Journal of Systematic and Evolutionary Microbiology, 52(5), 1551-1558. https://doi.org/10.1099/00207713-52-5-1551

De Roos, J., Verce, M., Aerts, M., Vandamme, P., De Vuyst, L., Schaffner, D. W. (2018). Temporal and spatial distribution of the acetic acid bacterium communities throughout the wooden casks used for the fermentation and maturation of lambic beer underlines their functional role. Applied and Environmental Microbiology, 84(7), e02846-17. https://doi. org/10.1128/AEM.02846-17

De Roos, J., De Vuyst, L. (2018). Acetic acid bacteria in fermented foods and beverages. Current Opinion in Biotechnology, 49, 115-119. https://doi. org/10.1016/j.copbio.2017.08.007

De Roos, J., Verce, M., Weckx, S., De Vuyst, L. (2020). Temporal shotgun metagenomics revealed the potential metabolic capabilities of specific microorganisms during lambic beer production. Frontiers in Microbiology, 11, 1692. https://doi.org/10.3389/fmicb.2020.01692

Dellaglio, F., Cleenwerck, I., Felis, G., Engelbeen, K., Janssens, D., Marzotto, M. (2005). Description of Gluconacetobacter swingsii sp nov and Gluconacetobacter rhaeticus sp nov., isolated from Italian apple fruit. International Journal of Systematic and Evolutionary Microbiology, 55(6), 2365-2370. https://doi.org/10.1099/ijs.0.63301-0

Gomes, R. J., Borges, M. de F., Rosa, M. de F., Castro-Gómez, R. J. H., Spinosa, W. A. (2018). Acetic acid bacteria in the food industry: systematics, characteristics and applications. Food Technology and Biotechnology, 56(2), 139-151. https://doi.org/10.17113/ftb.56.02.18.5593

González, Á., Guillamón, J. M., Mas, A., Poblet, M. (2006). Application of molecular methods for routine identification of acetic acid bacteria. International Journal of Food Microbiology, 108(1), 141-146. https:// doi.org/10.1016/j.ijfoodmicro.2005.10.025

González, Á., Hierro, N., Poblet, M., Mas, A., Guillamón, J. M. (2005). Application of molecular methods to demonstrate species and strain evolution of acetic acid bacteria population during wine production. International Journal of Food Microbiology, 102(3), 295-304. https:// doi.org/10.1016/j.ijfoodmicro.2004.11.020

González, Á., Hierro, N., Poblet, M., Mas, A., Guillamón, J. M. (2006). Enumeration and detection of acetic acid bacteria by real-time PCR and nested PCR. FEMS Microbiology Letters, 254(1), 123-128. https://doi. org/10.1111/j.1574-6968.2005.000011.x

González, Á., Hierro, N., Poblet, M., Rozès, N., Mas, A., Guillamón, J. M. (2004). Application of molecular methods for the differentiation of acetic acid bacteria in a red wine fermentation. Journal of Applied Microbiology, 96(4), 853-860. https://doi.org/10.1111/j.1365-2672.2004.02220.x Gullo, M., Caggia, C., Vero, L. D., Giudici, P. (2006). Characterization of acetic acid bacteria in "traditional balsamic vinegar." International Journal of Food Microbiology, 106(2), 209-212. https://doi.org/10.1016/j. ijfoodmicro.2005.06.024

Gullo, M., Giudici, P. (2008). Acetic acid bacteria in traditional balsamic vinegar: Phenotypic traits relevant for starter cultures selection. International Journal of Food Microbiology, 125(1), 46-53. https://doi. org/10.1016/j.ijfoodmicro.2007.11.076

Gupta, A., Singh, V. K., Qazi, G. N., Kumar, A. (2001). Gluconobacter oxydans: its biotechnological applications. Journal of Molecular Microbiology and Biotechnology, 3(3), 445-456.

Hill, A. E. (Ed.). (2015). Brewing Microbiology. Managing Microbes, Ensuring Quality and Valorising Waste. Woodhead Publishing, pp. 506. ISBN 978-1-78242-331-7

Hommel, R. K., Ahnert, P. (1999). Acetobacter. In R. K. Robinson (Ed.), Encyclopedia of Food Microbiology (pp. 1-7). Oxford: Elsevier. https:// doi.org/10.1006/rwfm.1999.0005

Ingledew, W. M. (1979). Effect of bacterial contaminants on beer. A review. Journal of the American Society of Brewing Chemists, 37(3), 145-150. https://doi.org/10.1080/03610470.1979.11960113

Jevons, A. L., Quain, D. E. (2021). Draught beer hygiene: use of microplates to assess biofilm formation, growth and removal. Journal of the Institute of Brewing, 127(2), 176-188. https://doi.org/10.1002/jib.637

Kersters, K., Lisdiyanti, P., Komagata, K., Swings, J. (2006). The Family Acetobacteraceae: The Genera Acetobacter, Acidomonas, Asaia, Gluconacetobacter, Gluconobacter, and Kozakia. In M. Dworkin, S. Falkow, E. Rosenberg, K. H. Schleifer, \& E. Stackebrandt (Eds.), The Prokaryotes: Volume 5: Proteobacteria: Alpha and Beta Subclasses (pp. 163-200). New York, NY: Springer New York. https://doi.org/10.1007/0-38730745-1_9

Lisdiyanti, P., Kawasaki, H., Seki, T., Yamada, Y., Uchimura, T., Komagata, K. (2000). Systematic study of the genus Acetobacter with descriptions of Acetobacter indonesiensis sp. nov., Acetobacter tropicalis sp. nov., Acetobacter orleanensis (Henneberg 1906) comb. nov., Acetobacter lovaniensis (Frateur 1950) comb. nov., and Acetobacter estunensis (Carr 1958) comb. nov. The Journal of General and Applied Microbiology, 46(3), 147-165. https://doi.org/10.2323/jgam.46.147

Lynch, K., Zannini, E., Wilkinson, S., Daenen, L., Arendt, E. (2019). Physiology of acetic acid bacteria and their role in vinegar and fermented beverages. Comprehensive Reviews in Food Science and Food Safety, 18(3), 587-625. https://doi.org/10.1111/1541-4337.12440

Maifreni, M., Frigo, F., Bartolomeoli, I., Buiatti, S., Picon, S., Marino, M. (2015). Bacterial biofilm as a possible source of contamination in the microbrewery environment. Food Control, 50, 809-814. https://doi. org/10.1016/j.foodcont.2014.10.032

McDonnell, G., Russell, A. D. (1999). Antiseptics and disinfectants: activity, action, and resistance. Clinical Microbiology Reviews, 12(1), 147-179. https://doi.org/10.1128/CMR.12.1.147

Nanda, K., Taniguchi, M., Ujike, S., Ishihara, N., Mori, H., Ono, H., Murooka, Y. (2001). Characterization o facetic acid bacteria in traditional acetic acid fermentation of rice vinegar (komesu) and unpolished rice vinegar (kurosu) produced in Japan. Applied and Environmental Microbiology, 67(2), 986-990. https://doi.org/10.1128/AEM.67.2.986990.2001

Papalexandratou, Z., Cleenwerck, I., De Vos, P., De Vuyst, L. (2009). (GTG)5-PCR reference framework for acetic acid bacteria. FEMS Microbiology Letters, 301(1), 44-49. https://doi.org/10.1111/j.15746968.2009.01792.x 
Paradh, A. D. (2015). 8 - Gram-negative spoilage bacteria in brewing. In A. E. Hill (Ed.), Brewing Microbiology (pp. 175-194). Oxford: Woodhead Publishing. https://doi.org/10.1016/B978-1-78242-331-7.00008-3

Parte, A. C., Sardà Carbasse, J., Meier-Kolthoff, J. P., Reimer, L. C., Göker, M. (2020). List of Prokaryotic names with Standing in Nomenclature (LPSN) moves to the DSMZ. International Journal of Systematic and Evolutionary Microbiology, 70(11), 5607-5612. https://doi. org/10.1099/ijsem.0.004332

Ploss, M. J., Erber, J. U., Eschenbecher, F. (1979). Die eissigäurebakterien in der brauerei. In Proceedings of the European brewery convention congress Berlin (pp. 521-532). Dordrecht: DSW.

Poblet, M., Rozès, N., Guillamón, J. M., Mas, A. (2000). Identification of acetic acid bacteria by restriction fragment length polymorphism analysis of a PCR-amplified fragment of the gene coding for 16S rRNA. Letters in Applied Microbiology, 31(1), 63-67. https://doi.org/10.1046/j.1472765x.2000.00765.x

Ruiz, A., Poblet, M., Mas, A., Guillamón, J. M. (2000). Identification of acetic acid bacteria by RFLP of PCR-amplified 16S rDNA and 16S-23S rDNA intergenic spacer. International Journal of Systematic and Evolutionary Microbiology. Microbiology Society. https://doi. org/10.1099/00207713-50-6-1981

Saichana, N., Matsushita, K., Adachi, O., Frébort, I., Frebortova, J. (2015). Acetic acid bacteria: A group of bacteria with versatile biotechnological applications. Biotechnology Advances, 33(6, Part 2), 1260-1271. https://doi.org/10.1016/j.biotechadv.2014.12.001

Sakamoto, K., Konings, W. N. (2003). Beer spoilage bacteria and hop resistance. International Journal of Food Microbiology, 89(2), 105-124. https://doi.org/10.1016/S0168-1605(03)00153-3

Schoch, C. L., Ciufo, S., Domrachev, M., Hotton, C. L., Kannan, S., Khovanskaya, R., ... Karsch-Mizrachi, I. (2020). NCBI Taxonomy: a comprehensive update on curation, resources and tools. Database: The Journal of Biological Databases and Curation, 2020, baaa062. https://doi. org/10.1093/database/baaa062

Sengun, I. Y., Karabiyikli, S. (2011). Importance of acetic acid bacteria in food industry. Food Control, 22(5), 647-656. https://doi. org/10.1016/j.foodcont.2010.11.008

Sievers, M., Swings, J. (2015). Acetobacteraceae. In Bergey's Manual of Systematics of Archaea and Bacteria (pp. 1-20). American Cancer Society. https://doi.org/10.1002/9781118960608.fbm00174

Snauwaert, I., Roels, S. P., Nieuwerburgh, F. V., Landschoot, A. V., Vuyst, L. D., Vandamme, P. (2016). Microbial diversity and metabolite composition of Belgian red-brown acidic ales. International Journal of Food Microbiology, 221, 1-11. https://doi.org/10.1016/j.ijfoodmicro.2015.12.009

Spitaels, F., Li, L., Wieme, A., Balzarini, T., Cleenwerck, I., Van Landschoot, A., ... Vandamme, P. (2014). Acetobacter lambici sp. nov., isolated from fermenting lambic beer. International Journal of Systematic and Evolutionary Microbiology, 64(Pt4), 1083-1089. https://doi.org/10.1099/ ijs.0.057315-0

Spitaels, F., Wieme, A., Balzarini, T., Cleenwerck, I., Van Landschoot, A., De Vuyst, L., Vandamme, P. (2014). Gluconobacter cerevisiae sp. nov., isolated from the brewery environment. International Journal of Systematic and Evolutionary Microbiology, 64(Pt4), 1134-1141. https://doi. org/10.1099/ijs.0.059311-0

Storgårds, E. (2000). Process hygiene control in beer production and dispensing (Espoo 2000). Finland: Technical Research Centre of Finland, VTT Publicatios. Retrieved from https://www.vttresearch.com/sites/ default/files/pdf/publications/2000/P410.pdf
Tanasupawat, S., Kommanee, J., Malimas, T., Yukphan, P., Nakagawa, Y., Yamada, Y. (2009). Identification of Acetobacter, Gluconobacter, and Asaia strains isolated in Thailand based on 16S-23S rRNA gene internal transcribed spacer restriction and 16S rRNA gene sequence analyses. Microbes and Environments, 24(2), 135-143. https://doi. org/10.1264/jsme2.ME08564

Timke, M., Wolking, D., Wang-Lieu, N. Q., Altendorf, K., Lipski, A. (2004). Microbial composition of biofilms in a brewery investigated by fatty acid analysis, fluorescence in situ hybridisation and isolation techniques. Applied Microbiology and Biotechnology, 66(1), 100-107. https://doi. org/10.1007/s00253-004-1601-y

Trcek, J., Ramus, J., Raspor, P. (1997). Phenotypic characterization and RAPD-PCR profiling of Acetobacter sp. isolated from spirit vinegar production. Food Technology and Biotechnology, 35(1), 63-67.

Trcek, J., Teuber, M. (2002). Genetic and restriction analysis of the 16S-23S rDNA internal transcribed spacer regions of the acetic acid bacteria. FEMS Microbiology Letters, 208(1), 69-75. https://doi.org/10.1016/ S0378-1097(01)00593-6

Trcek, J. (2005). Quick identification of acetic acid bacteria based on nucleotide sequences of the 16S-23S rDNA internal transcribed spacer region and of the PQQ-dependent alcohol dehydrogenase gene. Systematic and Applied Microbiology, 28(8), 735-745. https://doi. org/10.1016/j.syapm.2005.05.001

Van Vuuren, H. J. J., Priest, F. G. (2003). Gram-negative brewery bacteria. In F. G. Priest \& I. Campbell (Eds.), Brewing Microbiology (pp. 219-245). Boston, MA: Springer US. https://doi.org/10.1007/978-1-44199250-5_6

Van Vuuren, H., Loos, M., Louw, H., Meisel, R. (1979). Distribution of bacterial contaminants in a South-African lager brewery. Journal of Applied Bacteriology, 47(3), 421-424. https://doi.org/10.1111/ j.1365-2672.1979.tb01202.x

Vero, L. D., Gala, E., Gullo, M., Solieri, L., Landi, S., Giudici, P. (2006). Application of denaturing gradient gel electrophoresis (DGGE) analysis to evaluate acetic acid bacteria in traditional balsamic vinegar. Food Microbiology, 23(8), 809-813. https://doi.org/10.1016/j. fm.2006.01.006

Vriesekoop, F., Krahl, M., Hucker, B., Menz, G. (2012). 125th Anniversary Review: Bacteria in brewing: The good, the bad and the ugly. Journal of the Institute of Brewing, 118(4), 335-345. https://doi.org/10.1002/ jib.49

Vuyst, L. D., Camu, N., Winter, T. D., Vandemeulebroecke, K., Perre, V. V. de, Vancanneyt, M., ...Cleenwerck, I. (2008). Validation of the (GTG)5-repPCR fingerprinting technique for rapid classification and identification of acetic acid bacteria, with a focus on isolates from Ghanaian fermented cocoa beans. International Journal of Food Microbiology, 125(1), 79-90. https://doi.org/10.1016/j.ijfoodmicro.2007.02.030

Wang, B., Shao, Y., Chen, F. (2015). Overview on mechanisms of acetic acid resistance in acetic acid bacteria. World Journal of Microbiology \& Biotechnology, 31(2), 255-263. https://doi.org/10.1007/s11274015-1799-0

Wieme, A. D., Spitaels, F., Aerts, M., De Bruyne, K., Van Landschoot, A., Vandamme, P. (2014). Identification of beer-spoilage bacteria using matrix-assisted laser desorption/ionization time-of-flight mass spectrometry. International Journal of Food Microbiology, 185, 41-50. https://doi.org/10.1016/j.ijfoodmicro.2014.05.003 